\title{
Impact of Body Mass Index and Leptin on Response of Non- Hodgkin's Lymphomas to Chemotherapy
}

\author{
Ali E. Ali ${ }^{\text {a }}$, Nabil E. Khattab ${ }^{\text {a }}$, Hanan R. Nassar ${ }^{\text {b }}$, Abd Elmonem A. Abd Elmonem ${ }^{\text {a }}$, Hiam \\ Abdallah $^{\mathrm{a}}$, Mohamed Ahmed ${ }^{\mathrm{a}}$
}

\begin{abstract}
a medicine of internal medicine, Benha University, Egypt. ${ }^{\mathrm{b}}$ Department of medical Oncology, National Cancer Institute, Cairo University, Egypt

Correspondence to: Hiam Abdallah, Department of internal medicine, Benha faculty of medicine, Benha University, Egypt.
\end{abstract}

Email:

hiameleimy@gmail.com

Received: 2 March 2020

Accepted: 16 April 2020

\begin{abstract}
Background: Obesity is a positive chronic imbalance between energy intake and expenditure mediated through leptin signaling pathway. Obesity is associated with increased incidence and mortality of cancer, including non-Hodgkin's lymphoma (NHL). Associations between polymorphisms in leptin and leptin receptor genes and non-Hodgkin's lymphomas have been reported. Aim of study: evaluate the impact of body mass index and serum leptin level on response of NHL patients to chemotherapy. Subjects and methods: 100 NHL adult patients were included. For each patient, body mass index was determined. Investigations performed include laboratory (complete blood count, serum levels of lactate dehydrogenase, liver enzymes, bilirubin, albumin, creatinine, uric acid, and lipid profiles, and serum leptin level), imaging (pelvi-abdominal ultrasonography, computerized tomography scans and positron-emission tomography), and pathologic examination of biopsy samples. Appropriate chemotherapy regimens
\end{abstract} were given for 6 cycles, and then the patients were re-assessed to determine their response to chemotherapy. Results: Positive correlation was observed between body mass index and serum leptin level. Serum leptin level was higher in non-Hodgkin's lymphoma patients presented with B symptoms compared to those without B symptoms. Body mass index and serum leptin levels were significantly higher in patients with stage-4 disease compared to those with stage-1. Also, body mass index and leptin levels were significantly higher in patients who did not respond to chemotherapy and showed progressive disease compared to those who showed regressive response. Conclusion: Increased body mass index and elevated serum leptin level had a worse impact on response of non-Hodgkin's lymphoma patients to chemotherapy.

Key words: Body mass index, leptin, non-Hodgkin's lymphoma, response to chemotherapy. 



\section{Introduction}

Obesity is a positive chronic imbalance between energy intake and expenditure mediated through leptin (LEP) signaling pathway ${ }^{[1]}$. Incidence of obesity has increased dramatically throughout the last decades, and it represents a prominent risk factor in multiple disease conditions ${ }^{[2]}$. Obesity is linked to a general increase in incidence and mortality of cancer, and it might be associated with an increased risk of non-Hodgkin's lymphoma (NHL) [3]. Incidence of diffuse large B-cell lymphoma (DLBCL) increased in patients with higher body mass index (BMI) ${ }^{[4]}$.

Obesity results in a pathologic state of chronic low-level inflammation and altered immune responses that may influence B- and T-lymphocyte function and, thus, the development of NHL ${ }^{[5]}$. Obesity can also cause changes in the metabolism of endogenous hormones, which could distort the normal balance between cell proliferation, differentiation and apoptosis; thus, obesity may be a risk factor for nonHodgkin's lymphoma ${ }^{[6]}$. Weight loss greater than $10 \%$ is regarded as one of the B- symptoms (fever, night sweats, weight loss) that may present in lymphoma patients at diagnosis ${ }^{[7]}$.

Adipocytes secrete highly-active biological molecules like leptin, resistin, and adiponectin ${ }^{[1]}$. Adipocyte-derived adipokines may act as mediators in the NHL pathogenesis ${ }^{[5]}$. Leptin, a 16-kD (kiloDalton) polypeptide, has a role in nutrient intake and in regulation of metabolism. Leptin receptor (LEPR) was expressed on CD34+ hematopoietic stem cells and leptin had influence on maturation and proliferation of normal hematopoietic cells ${ }^{[1]}$. Leptin participates in the inflammation response and enhances B-cell survival ${ }^{[5]}$.

Associations between polymorphisms in LEP and LEPR genes and non-Hodgkin's lymphoma have been reported ${ }^{[8]}$. It was reported that LEP A19G allele was associated with NHL risk ${ }^{[9]}$ and that LEPR Q223R genotype was associated with increased risk of follicular lymphoma (FL) among women ${ }^{[10]}$. Some studies in developed countries concluded that obesity was a risk factor in NHLs ${ }^{[8]}$. 


\section{Aim of study:}

Whether obesity and leptin level could change the response of NHL patients to chemotherapy is less well-studied. Thus, this study aimed to evaluate the impact of body mass index (BMI) and serum leptin level on response of Egyptian non-Hodgkin's lymphoma patients to chemotherapy.

\section{Subjects and methods:}

This prospective multi-centers study was conducted at Internal Medicine Department, Benha University Hospital, and Medical Oncology Department, National Cancer Institute, Egypt, during the period from March 2018 to October 2019, including 100 adult patients with non-Hodgkin's lymphomas. This study was approved by the institutional ethics committee of Benha University Hospital and National Cancer Institute. The patients were informed about the nature of study and a written consent was obtained from each one. Patients with newlydiagnosed NHL, aged 18 years or older, males or females, and with various body mass indices were included. Exclusion criteria included patients with relapsed NHL, patients with NHL who already started chemotherapy regimens, patients with history of prior receiving NHL chemotherapies, and patients with history of other malignancies. Full medical history was obtained and thorough physical examination was done. The patients' weights and heights were measured, and the BMI was determined for each patient according to the formula: $\mathrm{BMI}=$ $\mathrm{Wt} / \mathrm{Ht}^{2}$, where $\mathrm{BMI}$ is body mass index, $\mathrm{Wt}$ is weight in kilograms, and $\mathrm{Ht}^{2}$ is square of height in meters. The BMI is expressed in $\mathrm{kg} / \mathrm{m}^{2}$, and the patients were categorized into patients with normal body weight (BMI of 18.5-24.9 kg/m ${ }^{2}$ ), overweight (BMI of 25$29.9 \mathrm{~kg} / \mathrm{m}^{2}$ ), stage-I obesity (BMI of 30-34.9 $\mathrm{kg} / \mathrm{m}^{2}$ ), stage-II obesity (BMI of 35-39.9 $\mathrm{kg} / \mathrm{m}^{2}$ ), and stage-III obesity (BMI of $\geq 40$ $\left.\mathrm{kg} / \mathrm{m}^{2}\right)^{[11]}$.

Venous blood sample $(5 \mathrm{~mL})$ were obtained from antecubital vein under complete aseptic conditions, centrifuged at $1000 \mathrm{xg}$ for 10 minutes, and the serum was separated and stored at $-10{ }^{\circ} \mathrm{C}$ or lower for later determination of various serum parameters ${ }^{[12]}$. The following laboratory investigations were performed: complete blood count (CBC), serum levels of lactate dehydrogenase (LDH), alanine transaminase (ALT), aspartate transaminase (AST), bilirubin (total, direct, and indirect), albumin, creatinine, lipid profile, and uric acid. Serum 
leptin levels were evaluated for all patients at their presentation before staring treatment regimens using enzyme immunoassay (EIA) method ${ }^{[13]}$. Serum leptin level was expressed in $\mathrm{ng} / \mathrm{mL}$ (nanogram/milliliter), with a normal value of $7.4 \mathrm{ng} / \mathrm{mL}$ (range, 3.7-11.1) in females and of $3.8 \mathrm{ng} / \mathrm{mL}$ (range 2.0-5.6 $\mathrm{ng} / \mathrm{mL}$ ) in males ${ }^{[14]}$. Biopsy samples were obtained from affected lesions and examined histopathologically to confirm the diagnosis of NHL and to determine its pathological subtypes; also flow cytometry and immunohistochemistry studies were done ${ }^{[15]}$. Imaging studies were carried out, including pelvi-abdominal ultrasonography, chest $\mathrm{X}$ ray, computed tomography "CT" scans on neck, chest, abdomen, and pelvis, and positron emission tomography (PET) scan.

According to NHL pathologic subtype, 6 cycles of the appropriate chemotherapy regimen were given for each patient. Four chemotherapy regimens were used: CHOP (cyclophosphamide, doxorubicin "hydroxydaunorubicin", vincristine "oncovin", prednisone) regimen given to patients with Burkitt lymphoma and patients with follicular lymphoma; R-CHOP (rituximab plus $\mathrm{CHOP}$ ) regimen given to patients with DLBCL; CVP (cyclophosphamide, vincristine "oncovin", prednisone) regimen given to patients with mantel cell lymphoma and patients with
MALT (mucosa-associated lymphoid tissue) lymphoma; and FC (fludarabine, cyclophosphamide) regimen given for patients with T-cell lymphoma and patients with CLL (chronic lymphocytic leukemia) [16]. After finishing their 6-cycle chemotherapy regimens, the patients were reassessed by pan CT scans with contrast, and their response to chemotherapy were categorized into regressive (respond to chemotherapy), stationary, and progressive ${ }^{[17]}$, as follows:

i-Regressive: characterized by;

-lymph nodes and extra-lymphatic sites: target nodes/nodal mass regress to $1.5 \mathrm{~cm}$ in longest transverse diameter, and no extralymphatic sites of disease.

-non-measured lesion: no applicable.

-organ enlargement: should regress to normal.

-new lesions: none.

ii-Stationary: characterized by;

-lymph nodes and extra-lymphatic sites: target nodes/nodal masses show $<50 \%$ decrease in baseline, and extra-lymphatic sites without criteria for progression.

-non-measured lesions: no increase consistent with progression. 
-organ enlargement: no increase consistent with progression.

-new lesions: none.

iii-Progressive: characterized by;

-lymph nodes and extra-lymphatic sites: target nodes/nodal masses $>1.5 \mathrm{~cm}$ in longest transverse diameter or show $>50 \%$ increase in baseline and new or recurrent splenomegaly.

-non-measured lesions: re-growth of previously resolved lesions.

-organ enlargement: new or re-growth.

-new lesions: new or recurrent involvement.

\section{Statistical Analysis:}

Statistical analyses were done using SPSS (Statistical Package of Social Science) version 25 (IBM, Armonk, New York, United States). Quantitative data were expressed in numbers, range, mean, and standard deviation (SD). Qualitative data were expressed in frequencies and percentage. Student t-test was used for comparison of the mean values of two groups of quantitative data. ANOVA test ( $\mathrm{F}$ value) was used for relationships between variables using Pearson correlation test for parametric data and Spearman correlation test for non- parametric data. $\mathrm{P}$ value less than $0.05(\mathrm{P}<$ 0.05) was considered statistically significant; $\mathrm{P}$ value > 0.01 was considered highlysignificant ${ }^{[18]}$.

\section{Results:}

This prospective multi-centers study included 100 NHL patients, 70 males (70\%) and 30 females $(30 \%)$, with a mean age \pm SD of $50.2 \pm 16.8$ years (range, $22-83$ years). The frequencies and percentages of studied patients regarding various parameters are shown in table 1. Significant positive correlation was observed between BMI and serum leptin levels (figure 1). Serum leptin level in female patients with NHLs $(26.1 \pm 16.4 \mathrm{ng} / \mathrm{mL})$ was significantly higher than its level in male patients $(15.5 \pm 8.4$ $\mathrm{ng} / \mathrm{mL})(\mathrm{t}=4.29 ; \mathrm{p}=0.001)$ (table 3$)$. Serum leptin level in NHL patients presented with B symptoms, i.e., fever, sweating, weight loss, $(22.9 \pm 15.2 \mathrm{mg} / \mathrm{mL})$ was significantly higher compared to its level in patients without B symptoms $(14.4 \pm 6.2 \mathrm{ng} / \mathrm{mL})(\mathrm{t}=3.64 ; \mathrm{p}=$ 0.001) (table 3).

The values of BMI showed significant differences among patients with various disease stages, where the mean $\mathrm{BMI} \pm \mathrm{SD}$ in patients with stage-1 disease was $22.5 \pm 2.1$ $\mathrm{kg} / \mathrm{m}^{2}$, in patients with stage-2 disease was 
$25.5 \pm 3.9 \mathrm{~kg} / \mathrm{m}^{2}$, in patients with stage- 3 disease was $22.5 \pm 4.1 \mathrm{~kg} / \mathrm{m}^{2}$, and in patients with stage-4 disease was $26.1 \pm 5.1 \mathrm{~kg} / \mathrm{m}^{2}(\mathrm{~F}=$ 4.19; $\mathrm{P}=0.002)($ table 2).

Also, serum leptin levels showed significant differences among patients with various disease stages, where mean serum leptin level $\pm \mathrm{SD}$ was $11.6 \pm 2.5 \mathrm{ng} / \mathrm{mL}$ in patients with stage-1 disease, $18.4 \pm 9.2 \mathrm{ng} / \mathrm{mL}$ in patients with stage-2 disease, $13.1 \pm 6.6 \mathrm{ng} / \mathrm{mL}$ in patients with stage- 3 disease, and $21.7 \pm 13.9$ $\mathrm{ng} / \mathrm{mL}$ in patients with stage- 4 disease $(\mathrm{F}=$ 2.97; $\mathrm{P}=0.015)$. It was revealed that, both BMI and serum leptin levels were significantly higher in patients with stage-2 and stage-4 disease compared to patients with stage-1 and stage-3 disease (table 2).

The results of this study also showed that the serum leptin level was significantly higher in patients with DLBCL lymphoma (22.4 \pm 12.1 $\mathrm{ng} / \mathrm{mL}$ ) and patients with mantel cell lymphoma $(26.3 \pm 8.1 \mathrm{ng} / \mathrm{mL})$ compared to other pathologic subtypes $(\mathrm{F}=2.61 ; \mathrm{P}=$ 0.022) (table 3) Significant correlation between BMI and response to chemotherapy was revealed in this study, where BMI \pm SD was $21.6 \pm 2.2 \mathrm{~kg} / \mathrm{m}^{2}$ in patients who showed regressive response, $23.4 \pm 3.4 \mathrm{~kg} / \mathrm{m}^{2}$ in patients who showed stationary lesions, $28.6 \pm 5.4 \mathrm{~kg} / \mathrm{m}^{2}$ in patients who showed progressive disease, and $25.8 \pm 1.6 \mathrm{~kg} / \mathrm{m}^{2}$ in patients who died during course of therapy $(\mathrm{F}$ $=17.57 ; \mathrm{P}=0.001)($ table 4 ; figure 2$)$.

Similar to BMI, significant correlation was also observed between serum leptin level and response to chemotherapy, where mean serum leptin level $\pm \mathrm{SD}$ in patients who responded to chemotherapy and showed regressive response was $10.5 \pm 4.1 \mathrm{mg} / \mathrm{mL}$, in patients who showed stationary lesions was 14.8 $\pm 7.9 \mathrm{ng} / \mathrm{mL}$, in patients who showed progressive disease was $27.6 \pm 15.5 \mathrm{ng} / \mathrm{mL}$, and in those who died during course of therapy was $19.2 \pm 2.7 \mathrm{ng} / \mathrm{mL}(\mathrm{F}=14.45 ; \mathrm{P}=$ 0.001) (table 4; figure 3). Both BMI and serum leptin levels were significantly higher in patients with progressive disease (i.e., not respond to chemotherapy) compared to those with regressive response (table 4). 
Benha medical journal vol. 38, issue 1, 2021

Table 1: Frequencies and percentages of studied patients regarding various parameters

Total number $=100$ patients

\begin{tabular}{|c|c|c|c|}
\hline \multicolumn{2}{|l|}{ parameters } & \multirow{2}{*}{$\begin{array}{l}\text { Number of patients } \\
70\end{array}$} & \multirow{2}{*}{$\begin{array}{l}\text { Percentages } \\
(\%) \\
70 \%\end{array}$} \\
\hline Sex & Males & & \\
\hline & Females & 30 & $30 \%$ \\
\hline \multirow[t]{2}{*}{ Obesity } & Obese & 48 & $48 \%$ \\
\hline & Non-obese & 52 & $52 \%$ \\
\hline \multirow[t]{4}{*}{ B symptoms } & Yes & 60 & $60 \%$ \\
\hline & No & 40 & $40 \%$ \\
\hline & Burkitt lymphoma & 10 & $10 \%$ \\
\hline & CLL & 12 & $12 \%$ \\
\hline \multirow[t]{6}{*}{ Pathological Types } & DLBCL & 44 & $44 \%$ \\
\hline & Follicular lymphoma & 14 & $14 \%$ \\
\hline & MALT lymphoma & 4 & $4 \%$ \\
\hline & Mantel cell lymphoma & 8 & $8 \%$ \\
\hline & T-cell lymphoma & 8 & $8 \%$ \\
\hline & Stage-1 & 16 & $16 \%$ \\
\hline \multirow[t]{4}{*}{ Stages } & Stage-2 & 16 & $16 \%$ \\
\hline & Stage-3 & 8 & $8 \%$ \\
\hline & Stage-4 & 60 & $60 \%$ \\
\hline & R-CHOP & 26 & $26 \%$ \\
\hline Chemotherapy & CHOP & 48 & $48 \%$ \\
\hline \multirow[t]{3}{*}{ Regimens } & CVP & 18 & $18 \%$ \\
\hline & FC & 8 & $8 \%$ \\
\hline & Regressive & 22 & $22 \%$ \\
\hline \multirow{3}{*}{$\begin{array}{l}\text { Response to } \\
\text { chemotherapy }\end{array}$} & Stationary & 34 & $34 \%$ \\
\hline & Progressive & 34 & $34 \%$ \\
\hline & Dead & 10 & $10 \%$ \\
\hline
\end{tabular}


Table 2: BMI and serum leptin levels in various NHL disease stages

Total number $=100$ patients

\begin{tabular}{|c|c|c|c|c|}
\hline $\begin{array}{l}\text { Disease stages } \\
\text { (n= number of } \\
\text { patients) }\end{array}$ & $\begin{array}{c}\text { BMI }\left(\mathbf{k g} / \mathbf{m}^{2}\right) \\
(\text { mean } \pm \text { SD })\end{array}$ & Statistical test & $\begin{array}{l}\text { Serum leptin level } \\
(\mathrm{ng} / \mathrm{mL})(\text { mean } \pm \text { SD })\end{array}$ & Statistical test \\
\hline Stage $1(n=16)$ & $22.5 \pm 2.1$ & & $11.6 \pm 2.5$ & \\
\hline Stage $2(n=16)$ & $25.5 \pm 3.9$ & $\mathrm{~F}=4.19$ & $18.4 \pm 9.2$ & $\mathrm{~F}=2.97$ \\
\hline Stage $3(n=8)$ & $22.5 \pm 4.1$ & $P=0.002$ & $13.1 \pm 6.6$ & $P=0.015$ \\
\hline Stage $4(n=60)$ & $26.1 \pm 5.1$ & & $21.7 \pm 13.9$ & \\
\hline
\end{tabular}

Table 3: Serum leptin level and some parameters

Total number $=100$ patients

\section{Parameters}

( $n=$ number of patients)

\begin{tabular}{llll}
\hline & Males $(\mathbf{n}=\mathbf{7 0})$ & $15.5 \pm 8.4$ & $\mathrm{t}=4.29$ \\
Sex & Females $(\mathbf{n}=\mathbf{3 0})$ & $26.1 \pm 16.4$ & $\mathrm{P}=0.001$ \\
Bes symptoms & No & $22.9 \pm 15.2$ & $\mathrm{t}=3.64$ \\
& Burkitt lymphoma $(\mathbf{n}=\mathbf{1 0})$ & $14.4 \pm 6.2$ & $\mathrm{P}=0.001$ \\
& CLL $(\mathbf{n}=\mathbf{1 2})$ & $12.9 \pm 5.3$ & $\mathrm{~F}=2.61$ \\
Pathological & Follicular lymphoma $(\mathbf{n}=\mathbf{1 4})$ & $14.1 \pm 2.6$ & $\mathrm{P}=0.022$ \\
Subtypes & MALT lymphoma $(\mathbf{n}=\mathbf{4})$ & $13.8 \pm 1.2$ & \\
& Mantel cell lymphoma $(\mathbf{n}=\mathbf{8})$ & $26.3 \pm 8.1$ & \\
& T-cell lymphoma $(\mathbf{n}=\mathbf{8})$ & $15.1 \pm 2.3$ & \\
\end{tabular}

Serum leptin level $(\mathrm{ng} / \mathrm{mL}) \quad$ Statistical test \& $($ mean \pm SD) 
Table 4: Response to chemotherapy according to BMI and serum leptin level

Total number $=100$ patients

\begin{tabular}{lllll}
\hline $\begin{array}{l}\text { Response to chemotherapy } \\
(\mathbf{n}=\text { number of patients) }\end{array}$ & $\begin{array}{l}\text { BMI } \\
(\mathbf{m e a n} \pm \mathbf{S D})\end{array}$ & $\begin{array}{l}\text { Statistical } \\
\text { test }\end{array}$ & $\begin{array}{l}\text { Serum leptin level } \\
(\mathbf{n g} / \mathbf{m L})(\mathbf{m e a n} \pm \mathbf{S D})\end{array}$ & Statistical test \\
\hline Regressive $(\mathbf{n}=\mathbf{2 2})$ & $21.6 \pm 2.2$ & & $10.5 \pm 4.1$ & \\
Stationary course $(\mathbf{n}=\mathbf{3 4}$ & $23.4 \pm 3.4$ & $\mathrm{~F}=17.57$ & $14.8 \pm 7.9$ & $\mathrm{~F}=14.45$ \\
Progressive $(\mathbf{n}=\mathbf{3 4})$ & $28.6 \pm 5.4$ & $\mathrm{P}=0.001$ & $27.6 \pm 15.5$ & $\mathrm{P}=0.001$ \\
Dead $(\mathbf{n}=\mathbf{1 0})$ & $25.8 \pm 1.6$ & & $19.2 \pm 2.7$ & \\
\hline
\end{tabular}

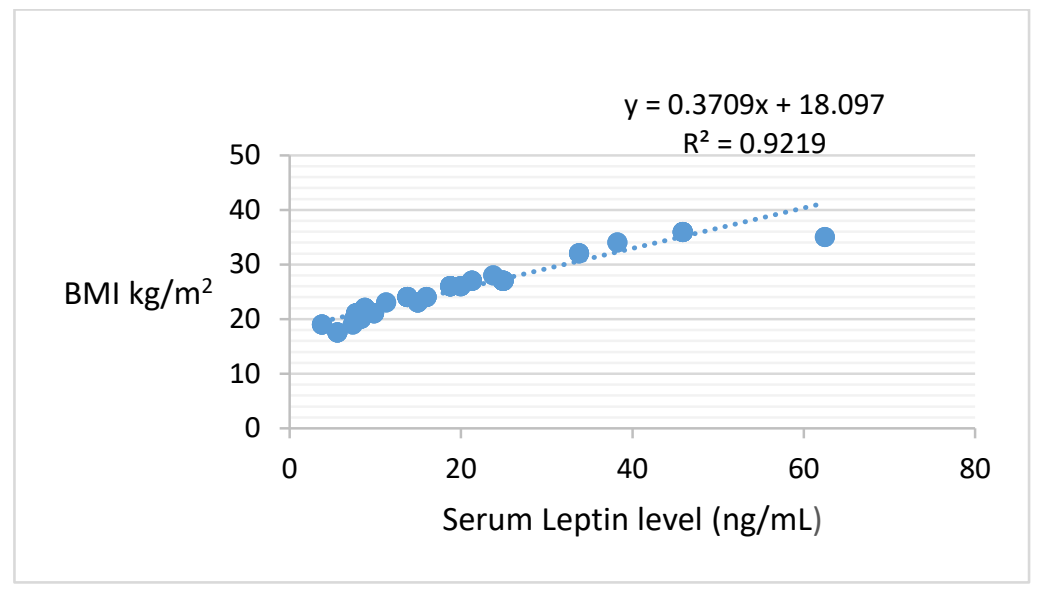

Figure 1: Correlation between BMI and serum leptin level

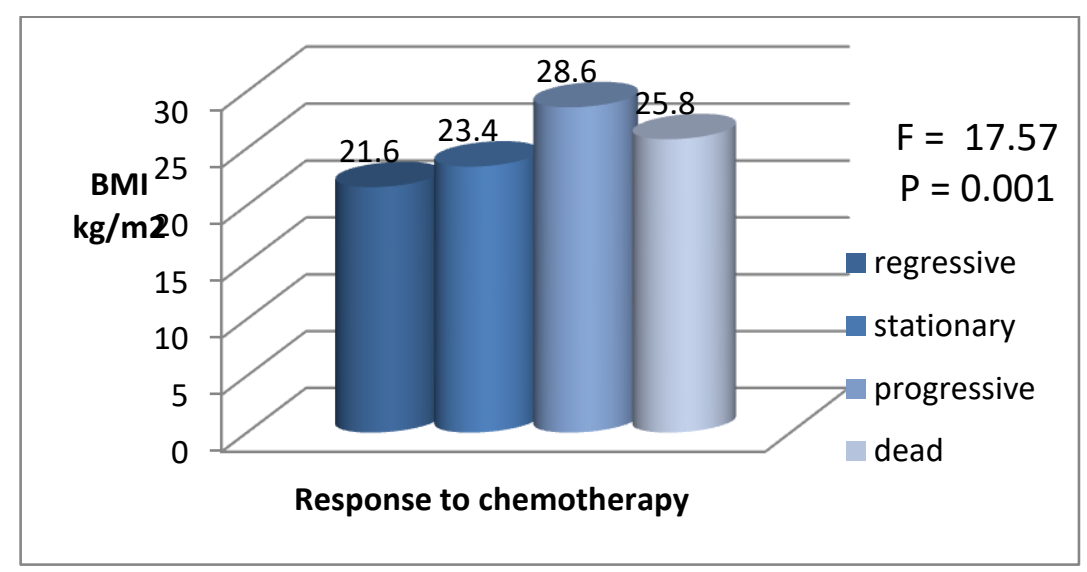

Figure 2: Response to chemotherapy regarding BMI 


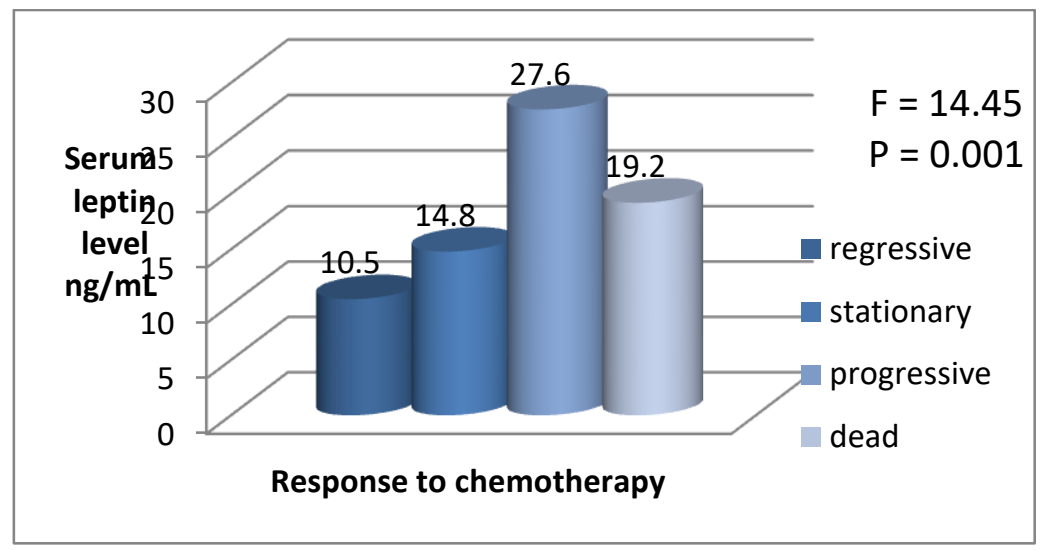

Figure 3: Response to chemotherapy regarding serum leptin levels

\section{Discussion:}

Higher BMI and hence obesity was associated with increased serum leptin level in the current study. Similarly, leptin level in adults was associated with obesity and increased body mass index ${ }^{[19]}$. In addition, obesity was related to increased leptin levels ${ }^{[20]}$. In current study, obesity was reported in $48 \%$ of NHL patients. Similarly, the risk of non-Hodgkin's lymphoma increased with obesity and this may be related to changes in circulating levels of adipocytokines, including leptin ${ }^{[21]}$. Besides their role in insulin resistance, these adipocytokines are involved in immunity and inflammation; several autoimmune and chronic inflammatory conditions have been associated with increased risk of nonHodgkin's lymphoma ${ }^{[22]}$. Obesity also gives rise to insulin resistance and compensatory hyperinsulinemia. Insulin may mediate tumorigenic effects directly through insulin receptors in pre-neoplastic target cells, or indirectly through alterations in endogenous hormone metabolism ${ }^{[23]}$. For instance, the elevated insulin levels lead to an increase in insulin-like growth factor-I (IGF-I), both of which can act as growth factors that promote cell proliferation and inhibit apoptosis ${ }^{[24]}$.

Serum leptin level in this study was significantly higher in patients presented with B symptoms than those without B symptoms. In contrast, serum leptin level has negative correlations with parameters of poor prognosis like IPI (international prognostic index) in non-Hodgkin's lymphomas ${ }^{[1]}$. In present study, serum leptin level was significantly higher in patients with DLBCL lymphoma and patients with mantel cell lymphoma. Consistently, leptin A19G polymorphism was significantly associated with decreased follicular lymphoma risk but 
not for DLBCL ${ }^{[8]}$. Additionally, overweight and obesity may be associated with an elevated risk of non-Hodgkin's lymphomas, particularly of DLBCL ${ }^{[21]}$.

In present study, patients with stage-4 NHL disease had significantly higher BMI compared to those with stage-1 disease. Serum leptin level, which is positivelycorrelated with BMI and obesity, was also significantly higher in NHL patients with stage-4 disease compared to those with stage1 disease. Because the response to chemotherapy is related to the disease stages and the response is bad with advanced stages, thus elevated BMI and serum leptin levels could affect the response of NHL patients to chemotherapy. Consistently, obesity was associated with impaired overall survival and increased rates of relapse in lymphoma patients undergoing high-dose chemotherapy (HDT) followed by autologous hematopoietic stem cell transplantation (auto-SHCT) ${ }^{[25]}$.

In current study, patients who showed regressive response had significantly lower BMI compared to those who showed progressive disease. Also, increased serum leptin, which is associated with obesity, had significant correlation with response to chemotherapy, where the serum leptin level was significantly higher in patients who did not respond to chemotherapy and showed progressive disease compared to those who showed regressive response. In agreement, an association between obesity and inferior outcomes in cancer patients was reported and, in addition, obesity was associated with impaired overall survival due to a higher incidence of relapse in lymphoma patients treated with HDT and concomitant autoHSCT ${ }^{[25]}$. In contrast, being underweight or obese at baseline and weight loss before or after diagnosis was associated with reduced overall survival of NHL ${ }^{[26]}$. Weight loss greater than $10 \%$ is regarded as one of NHL B-symptoms, which has been shown to be associated with worse prognosis and shortened survival ${ }^{[27]}$. This contrast could be explained by that the current study evaluated the impact of obesity on response to chemotherapy whereas the other studies ${ }^{[26]}$, [27] evaluated the impact of body weight changes before and after developing NHL as well as weight fluctuations near the time of treatment on the patients' survival. Also, in contrast to our results, weight gain during treatment was associated with better survival among NHL patients using chemotherapy ${ }^{[28]}$, and this contrast could be related to that our study evaluated the impact of obesity at patient's presentation on response to chemotherapy but we did not evaluate the 
correlation between weight gain during treatment with the patients' survival.

\section{Conclusion}

In conclusion, increased BMI and elevated serum leptin level had a worse impact on response of NHL patients to chemotherapy regardless of pathologic subtypes. Whether elevated BMI and leptin levels had a similar worse impact on response of various NHL pathologic subtypes to chemotherapy was not answered because the number of patients included in different NHL pathologic subtype groups was so little that making the statistical analysis difficult. Further studies are recommended to evaluate the impact of BMI and serum leptin level on response of different NHL pathologic subtypes to chemotherapy.

\section{Acknowledgment:}

Authors would like to thank all treating physicians, clinical pathologists, and other technical staff involved in dealing with and caring of the patients.

\section{References}

1- Pamuk G, Demir M, Harmandar F, Yesil Y, Turgut B, and Vural O (2006): Leptin and resistin levels in serum of patients with hematologic malignancies: correlation with clinical characteristics. Exp Oncol, 28(3): 241244.

2- Gonzalez P, Martinez M, Hu F, Despres J, Matsuzawa Y and Loos R (2017): Obesity. Nat Rev Dis Primers, 3:17034.

3- Larsson S and Wolk A (2011): Body mass index and risk of non-Hodgkin's and Hodgkin's lymphoma: a meta-analysis of prospective studies. Eur J Cancer, 47(16): 2422-2430.

4- Morton L, Slager S, Cerhan J, Wang S, Vajdic C, and Skibola C (2014): Etiologic heterogeneity among non-Hodgkin lymphoma subtypes: the InterLymph Non-Hodgkin Lymphoma Subtypes Project. J Natl Cancer Inst Monogr, 48: 130-144.

5- Conroy S, Maskarinec G, Morimoto Y, Franke A, Cooney E, Wilkemns L, et al (2013): NonHodgkin lymphoma and circulating markers of inflammation and adiposity in a Nested CaseControl Study: The multiethnic Cohort. Cancer Epidemiol Biomarkers Prev, 22(3): 337.

6- Tulinius S, Sigfusson N, Sigvaldason H, Bjarnadottir K and Tryggvadotti L (1997): Risk factors for malignant diseases: a cohort study on a population of 22,946 Icelanders. Cancer Epidemiol Biomarkers Prev, 6: 863-873.

7- Xuesong H, June S, and Patrick T (2013): Body mass index, weight change, and survival in nonHodgkin's lymphoma patients in Connecticut women. Nutrition and Cancer, 65(1): 43-50.

8- Hai-Yan L, Hui S, Chun-Yan L, Quan-Chi C, Tian-Bao H, Peng-Cheng L, et al (2015): LEP and LEPR polymorphisms in non-Hodgkin lymphoma risk: A systemic review and pooled analysis. JBUON, 20(1): 261-268.

9- Skibola C, Holly E and Forrest M (2004): Body mass index, leptin receptor polymorphisms, and non-Hodgkin lymphoma. Cancer Epidemiol Biomarkers Prev, 13: 779-786. 
10-Willett E, Skibola C, and Adamson P (2005): Non-Hodgkin's lymphoma, obesity and energy homeostasis polymorphisms. Br J Cancer, 93: 811-816.

11- Freedman DS, Horlick M, and Berenson GS (2013): A comparison of the Slaughter skinfoldthickness equations and BMI in predicting body fatness and cardiovascular disease risk factor levels in children. Am. J. Clin. Nutr., 98(6), 1417-1424.

12-Chessler S, Fujimoto W, Shofer J, Boyko E, and Weigle D (1998): Increased plasma leptin levels are associated with fat accumulation in Japanese Americans. Diabetes, 47: 239.

13-Dagogo-Jack S (1996): Plasma leptin and insulin relationships in obese and non-obese humans. Diabetes, 45; 695.

14-Maffei M, Halaas J, Ravussin E, Pratley R, Lee G, Zhang Y, et al (1995): Leptin levels in human and rodent: measurement of plasma leptin level and obRNA in obese and weight reduced subjects. Nat Med, 1: 1155.

15-Rouhani M, Haghighatdoost F, Surkan P, and Azadbakht L (2016): Associations between dietary energy density and obesity: a systematic review and meta-analysis of observational studies. Nutrition, 32(10): 1037-1047.

16-Marcus R, Imarie K, and Belch A (2005): CVP chemotherapy plus rituximab compared with CVP as first-line treatment for advanced follicular lymphoma. Blood, 105(4): 1417.

17-Cheson B, Fisher R, and Barrington S (2014): Recommendations for initial evaluation, staging, and response assessment of Hodgkin and nonHodgkin lymphoma: the Lugano classification. J Clin Oncol, 32: 30-59-3068.
18-Peacock J, Peacock L, and Peacock P (2011): Oxford handbook of medical statistics. Oxford University Press. Print Publication Dat Nov, Print ISBV-139780199551286.

19-Hirose H, Saito I, Kawai T, Nakamura K, Maruyama H, and Saruta T (1998): Serum leptin level: possible association with hematopoiesis in adolescents, independent of body mass index and serum insulin. Cli Sci, 94: 633-636.

20-Tilg H and Moschen R (2006): Adipocytokines: mediators linking adipose tissue, inflammation, and immunity. Nat Rev Immunol, 6:772-783.

21-Susanna C and Alicja W (2007): Obesity and risk of non-Hodgkin's lymphoma: a meta-analysis. Int. J Cancer, 121: 1564-1570.

22-Smedby K, Baecklund E and Askling J (2006): Malignant lymphoma in autoimmunity and inflammation: a review of risk factors, and lymphoma characteristics. Cancer Epidemiol Biomarkers Prev, 15: 2069-2077.

23-Calle E and Kaaks A (2004): Overweight, obesity and cancer: epidemiological evidence and proposed mechanisms. Nat Rev Cancer, 4: 579591.

24-Khandwala H, McCutcheon I, Flyvbjerg A, and Friend K (2000): The effect of insulin-like growth factors on tumorigenesis and neoplastic growth. Endocr Rev, 21: 215-244.

25-Scheich S, EnBle J, Mucke V, Acker F, Aspacher L, Xolf S, et al (2019): Obesity is associated with impaired survival in lymphoma patients undergoing autologous stem cell transplantation. Plose

one/https:1ldoi.org/10.1371/jounal.pone.0225035 , November 8.

26-Han X, Stevens J, and Bradshaw P (2013): Body mass index, weight change, and survival in non- 
Hodgkin's lymphoma patients in Connecticut women. Nutrition and Cancer, 65(1): 43-50.

27-Han X, Kilfoy B, Zheng T, Holford T, and Zhu C (2008): Lymphoma survival patterns by WHO subtype in the United States, 1973-2003. Cancer Causes Control, 19, 841-858.
28-Stanisavljevic N and Marisavljevic D (2010): Weight and body composition changes during $\mathrm{R}$ CHOP chemotherapy in patients with nonHodgkin's lymphoma and their impact on dose intensity and toxicity. J BUON, 15: 290-296.

To cite this article: Ali E. Ali, Nabil E. Khattab, Hanan R. Nassar, Abd Elmonem A. Abd Elmonem, Hiam Abdallah, Mohamed Ahmed. Impact of Body Mass Index and Leptin on Response of Non-Hodgkin's Lymphomas to Chemotherapy. BMFJ. 2021;38(1):27-40. DOI: 10.21608/bmfj.2020.25038.1223 